\title{
Optimalization of Qardhu Hasan Sharia Bank toward Decreasing Poverty in Bandung
}

\author{
Amir Machmud, Eeng Ahman, Navik Istikomah \\ Faculty of Business and Economic Education \\ Universitas Pendidikan Indonesia \\ Bandung, Indonesia \\ amir@upi.edu
}

\begin{abstract}
This study aim to analysis the level of efficiency and effectiveness functional Sharia Bank (qardhu hasan product) to empower poor communities in Bandung City. Research study using analysis descriptive. This research population are poor communities that got qardhu hasan, Sharia Bank in BandungWest Java. Collecting data trough interview technic and distributing questionnaires. The collected data were analyzed using qualitative and quantitative analysis. Qualitative analysis using a scoring system to each indicator in the questionnaire, while the quantitative analysis using different test average. Based on the research results as follows: First, the effectiveness of management qardhu hasan managed by LAZ more effective than managed by Sharia Bank. Second, Qardhu hasan Sharia banks have been able to bring changes to household incomes, awareness of saving and changing the paradigm, especially with regard to discipline in paying the installments as well as awareness of saving, and the third qualitatively qardhu hasan Sharia banks have been able to reduce poverty in the Bandung but according in statistic not shows significant effects
\end{abstract}

Keywords - Poverty, Qardhu Hasan, Efficiency, Effectiveness, Empowerment

\section{INTRODUCTION}

Poverty is a very interesting phenomenon to be studied, especially in Indonesia because of its relevance to the development trilogy, namely economic growth, equitable development results and national stability. The facts show that poverty can't be avoided from a country, including provincial and city / county as happened in the city of Bandung - West Java.

Based on the National Poverty In 2011, the amount of poverty in the city of Bandung reached 79573 . This condition has decreased compared with the data on poverty in 2008, which amounted to 84432 people. Thus, the poverty rate over the past three years has decreased 3.00 percent (Damayanti, 2012). An overview poverty is an indication that the construction carried out in the city have not been fully a benefit for all the people. Poverty alleviation programs have been conducted, but poverty remains a major problem in economic development in the city of Bandung, making systematic and continuous efforts are needed to overcome.
Islam view that poverty is a structural problem entirely because Allah has guaranteed rizki any creature that has been, is, and will be created (Sura 30:40; Surah 11:6) and at the same time Islam has closed opportunities for cultural poverty by giving obligations seek living for every individual (Sura 67:15). Each creature has its good fortune respectively (Sura 29:60), and they will not starve (Sura 20: 118-119). Islam declared war on poverty, and strive block it, as well as oversee the various possibilities that can bring it on, in order to save the faith, morals and deeds maintain domestic life, and protecting stability and public tranquility. This is in line with the opinion of Yusuf Al-Qardawy that the negative effects of indigence and poverty could undermine faith, morality and the breakdown of families and communities and the state.

Sharia bank as a manifestation of the Islamic economic practices have products related to the problem poverty, which is called Qardh Hasan. Qordhu Hasan is part of the product services provided by the Bank of Shari'ah to lend without expecting anything in return. In the literature of classical jurisprudence, qordhu categorized into tathowwu'i agreement or contract mutual help and not a commercial transaction. As for the foundation of this activity is the alQuran (al-Hadid, 11), Hadith (Reported by Ibn Majjah no 2421, Kitab al-Ahkam; Ibn Hibban and Baihaqi), and ijma Ulama. Qordhu hasan is a complementary product to donate funds very little effort or help the social sector (Social Fund). Qordhu nature does not provide financial benefits.

Source of funds qardhu hasan among other activities funded by zakat, donation and alms. In addition to the sources of funds of the people, the Shari'ah banking practitioners, as well as scholars, seen any other sources of funds that can be allocated to qordhu hasan i.e. earnings doubtful (doubt), as nostro services in conventional correspondent bank, the interest on collateral $\mathrm{L} / \mathrm{C}$ at a foreign bank. One consideration the utilization of these funds is a rule akhoffu dhororain (take harm smaller). This is because if the funds Muslims were left in the institutions of a non-Muslim could be used for something that is detrimental to Islam itself. For example ArabianMoslemfunds in banks in Switzerland Jews. Therefore, the parking fund better taken and used for the prevention of natural disasters or help Dhu'afa. 
fully for the benefit of the public. Thirdly, Islam encourages the development of infrastructure that provides broad benefits for society (pro-poor infrastructure).Islam encourages the development of infrastructure which has positive externalities in order to improve the capacity and efficiency of the economy. Fourth, Islam encourages the provision of basic public services in favor of the wider community (pro-poor public services). There are three areas of public service that gets the attention of Islam seriously: bureaucracy, education, and health. Fifth, Islam encourages equity and income distribution policies that favor the poor (pro-poor income distribution). There is three main instrument in an Islamrelated distribution of income is land ownership rules, the application of zakat, and advocate qardhu hasan, donation, and endowments. With the application of zakat, then there will be no concentration of wealth in the community group. Zakat also ensure that everyone will be guaranteed minimum living so it has a chance to get out of poverty. Furthermore, to ensure that the property is not only circulated among the wealthy. Islam also strongly encourages the rich to give qard, donation, and endowments. Thus Islam encourages poverty through the fulfillment of the basic needs of society, focusing on the development of the real sector, and the equitable distribution of development outcomes.

In epistemology qardhul word comes from the q-r-d means cutting. Said that because the property really cut if given to the borrower. Based on the hadith of the Prophet, the granting of loans by way of introduction al-qard more pleasing to God than to give shodaqoh. This is a description of a legitimate and unquestionable, and the Sunna of the Prophet and ijma 'ulama (Maslehuddin, 1994). The terminology, alqardhu alhasan (benevolent loan) is a loan that is granted solely on the basis of social obligation, in this case, the borrower is not required to return anything but a loan (Perwataatmadja and Antonio, 1999). The nature of al-alHasan qard this is no financial advantage (Antonio, 2001).

Qardh is a virtue or soft loans without compensation, usually for the purchase of fungible goods are goods that can be predicted and changed according to the weight, size, and number. In the classical fiqh literature, categorized in aqd tathawwui qardh or contract mutual help and not a commercial transaction. Qard hasan on sharia banking is one of the instruments of contract tabarru. Akad tabarru are all kinds of agreements regarding the not-for-profit transaction (a transaction non-profit), so in essence, it is qard hasan not intended to seek commercial advantage for banks or institutions that use this product. (Adiwarman Karim, 2003)

The object of the loan qardh, usually money or other means of exchange is a pure no-interest loan transaction when borrowers get cash from their owners in this case the bank and only obligated to refund the principal debt at a certain time in the future will come. Borrowing on their own initiative to restore greater said thank you. Akad is mainly used by the IDB. When providing soft loans to the government. This service costs are generally not more than $2.5 \%$, and during this time ranges between 1-2\%. (Ascarya, 2007). principles in achieving pro-poor budgeting namely: strict fiscal discipline, good governance, and the use of state budget 
The Basic Law Qardh contained in the Qur'an (Qur'an; 2, 245), which means that "Who will lend to the Allah a good loan (spend their wealth in the way of Allah), then Allah will double the payment to him with a double folding lot. And Allah narrows and paved (sustenance) and to him was us back in. "Sunnah, HR. Ibn Hiban "From Ibn Mas'ud r.a. that the Prophet said: it is not a Muslim, lend twice except same with giving him the once".

Rukun Qardh consists of Muqridh, muqtaridh, Qardh (Objects on loan and sighat. The Terms Qardh include Qardh are goods which are beneficial, and without sighat, contract Qiradh can't do. Benefit Qardh (1) Assist clients who have difficulty getting funding, (2 ) the Qardhul Hasan is the difference between a conventional Sharia banks, and (3) with the social mission is expected to enhance the good image and loyalty of people towards sharia banks.

\section{METHODOLOY}

The method used in this study is a descriptive study of analytics with data collection through interviews and structured questionnaires to poor community receiver qardhu hasan either directly or indirectly. The population in this study as many as 1140 receiver qardhu hasan poor communities Islamic Banking in Bandung - West Java. The sampling technique is disproportionatestratified do random sampling, which is a technique used to determine the number of samples for stratified population but less proportionately. The number of samples taken refer in Table Sugiyono (2011 - Appendix 2). This table illustrates the determination of the number of samples of a given population with level error of $1 \%, 5 \%$, and $10 \%$. In this study using error level of $5 \%$, so that the number of samples as many as 265 people. In addition to primary data, this study uses secondary data derived from sharia banks and institutions of zakat in the city Bandung.

The method of analysis in this research is conducted in three stage: 1) Literature study, 2) qualitative descriptive analysis stage, and 3) quantitative analysis stage. An explanation of these stages as follows. First stage literature study was done in order to understand the concepts related to the problem qardhu hasan and poverty. Literature made from various literature related to the topic of this study. Second, the stage of qualitative descriptive analysis was used to analyze the effectiveness and efficiency of qardhu hasan in empowering the poor. This stage is carried out in order knowing how far the concept of perfect targeting qardhu hasan Islamic banks can be implemented. Thirdly, quantitative phase analysis was done in order to know how far the optimization of qardhu hasan in alleviating poverty. Through this phase is expected to provide inputs in determining policy related to the problem of poverty.

\section{RESULT AND DISCUSSION}

\subsection{Overview Qardhu Hasan Sharia Bank in Bandung}

In Article 1 point 11 PBI No. 7/46 / PBI / 2005, qardh interpreted as lending and borrowing funds without compensation to the obligation of the borrower returns the loan principal in a lump sum or in installments within a certain period. Thus qardh financing will be granted only in an emergency (emergency), or it can also be given to SMEs at the beginning of its establishment, but has a good reputation within the meaning of honesty managers. As for financing this qardh minimum requirement to be met under Article 18 of Regulation No. 7/46 / PBI / 2005 are as follows:

a) The Bank may provide loans Qardh for customers based on agreement;

b) Customer must return the principal amount Qardh received at the agreed time;

c) Banks may charge to customers of administrative costs in connection with lending Qardh;

d) Customers can provide additional / contribute voluntarily to the Bank for not agreed in the Agreement;

e) In the event the customer can't restore some or all of its obligations at the agreed time because customers are not able to, then the Bank may extend the repayment period or remove the book part or all of customer lending at the expense of the loss of the Bank;

f) In the event customers classified afford and does not return part or all of its obligations at the agreed time, the Banks may impose penalties on late payment, payment obligations or sell customer collateral to cover the loan obligations of the customer;

g) Source Qardh loan fund for businesses that are social activities can be derived from capital gains from the fund set aside and infaq;

h) The source of funds Qardh loans for business activities that are bailout funds short-term commercial (short term financing) allowed from third party funds that are investment doesn't damage the interests of customer's owner of the funds.

Differences with financial of qardhu hasan which is a virtue loan is interest-free loan that besides also it is intended for customers who really can't afford but need funds to keep hold of his life. For that in qard al-hasan borrower is basically not required to return it In the event it is not able to repay. The development fund hasan Qardhu Islamic Bank in Bandung on until, in June 2013 can be seen in the following: 
TABLE I. FUND DEVELOPMENT QARDH ISLAMIC BANK "X" IN THE CITY OF BANDUNG IN 2013

\begin{tabular}{|c|l|}
\hline $\begin{array}{c}\text { Source of funding Qardh in } \\
\mathbf{2 0 1 2}\end{array}$ & Rp. 285.000 .000 \\
\hline Source of funding Qardh & \\
\hline $\begin{array}{c}\text { Infaq and shadaqoh } \\
\text { costumer }\end{array}$ & Rp. \\
\hline Mulct & Rp. $72.000 .000,--$ \\
\hline Donation / Hibah & Rp. - \\
\hline Revenue Non Halal & Rp. 17.000 .000 \\
\hline Other & Rp. $20.000 .000,-$ \\
\hline Total untilJune 2013 & Rp. 394.000 .000 \\
\hline
\end{tabular}

${ }^{\text {a. }}$ Source: Financial Statements

TABLE II. FUND DEVELOPMENT ZIS SHARIA BANK"X" IN BANDUNG

\begin{tabular}{|c|l|}
\hline Source of funding ZIS in 2012 & Rp. 375.000 .000 \\
\hline Sources of funds Zakat & \\
\hline Zakat from Bank & Rp. $3.000 .000,-$ \\
\hline Zakat from outside bank & Rp. $104.000 .000,-$ \\
\hline Infaqand Shadaqah & Rp. $15.000 .000,--$ \\
\hline Total until June 2013 & Rp. 495.000.000,-- \\
\hline \multicolumn{2}{|l}{${ }^{\text {b. }}$ Source:Financial Statements } \\
\hline
\end{tabular}

Based on the Tables 4.1 and 4.2 show there are sources of potential funds that can lift the economy of the people especially to help the poor community. Referring to PBI No. 14/26 / PBI / 2012 on Business Activities and Office Network Based on Core Capital Banks, that the activity in the social sphere include the establishment of Baitul Maal institutions which function to receive funds from zakat, infaq, charity, grants or funds other social and channeled to the zakat management organizations, as well as raising funds from the endowment money and distribute it to the managers of endowments in accordance with the legislation in force. PBI affirm that the Sharia banks in the disbursement of funds can't directly to the public but must go through LAZ organization. In a further management, product virtues of Islamic banks still have to distinguish the source of charity fund. If the charity fund came from ZIS then the distribution should to 8 asnaf class of recipients of ZIS is indigent, poor, Amilin, gharimin, convert, contrast with the recipients of the charity fund which comes from sources other than the ZIS such as fines and income of non-kosher, then the distribution should be told SMEs that have not capable for banking activity.

In the last three years (2008-2011) Qardhu hasan Sharia banks to be channeled directly to poor families has increased on average by 40 percent, but it is followed by the increase in the number of installments in arrears on average by $34 \%$. These conditions certainly affected the Non-Performing Loan (NPL) Qardhul loans with an average of $24 \%$, while Banks Indonesia set a maximum gross NPL rate of 5\% as the tolerance of the health of a bank. Hasan Qardhul NPL loans have exceeded the tolerances set by Banks Indonesia, so it can be considered that the loan qardhu hasan managed by Islamic banks in the city have not been optimal.The situation is different when qardhu hasan funds channeled to amil zakat institutions in their level of fluency is actually very smoothly, only a small portion is not smooth. And that's because of being pressured by the needs of her children's school. In addition, this condition is not released from mentoring programs conducted by Amil Zakat Institute before and after receiving qardhu hasan.

\subsection{Overview Receiver Qardhul Hasan in Bandung}

As mentioned as before that in the distribution of qardhu hasan must distinguish the source for different uses. The recipient's qardhu hasan Sharia bank in Bandung in general education background SLTA to downward with the business sector in governance is the trade sector as nasi kuning (yellow rice), fried foods, and a small shop. Their ages are in the range of 34 up to 54 years. More clearly seen in the following Picture :
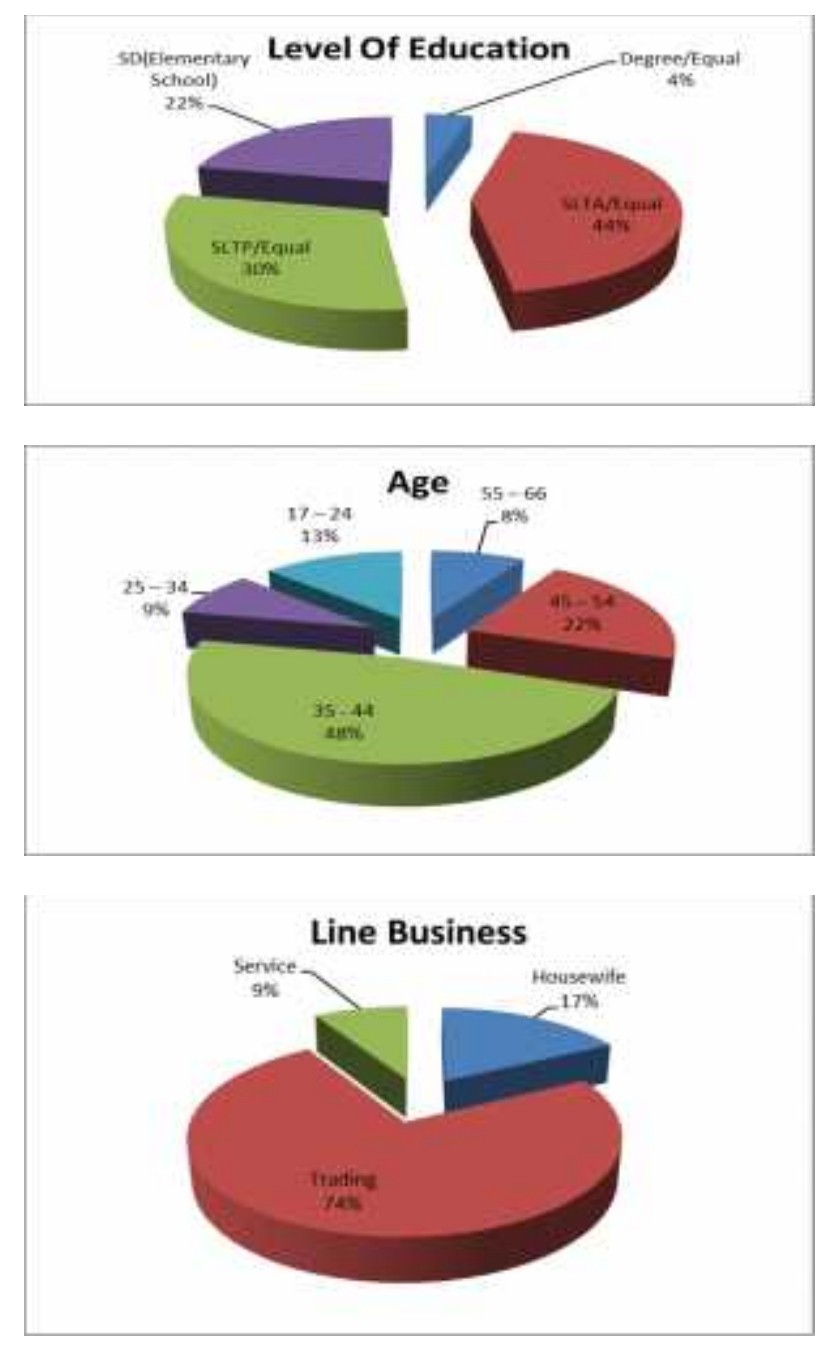

Fig. 1. Overview Receiver Qardhul Hasan Islamic Bank in Bandung. Source: Result of data processing 

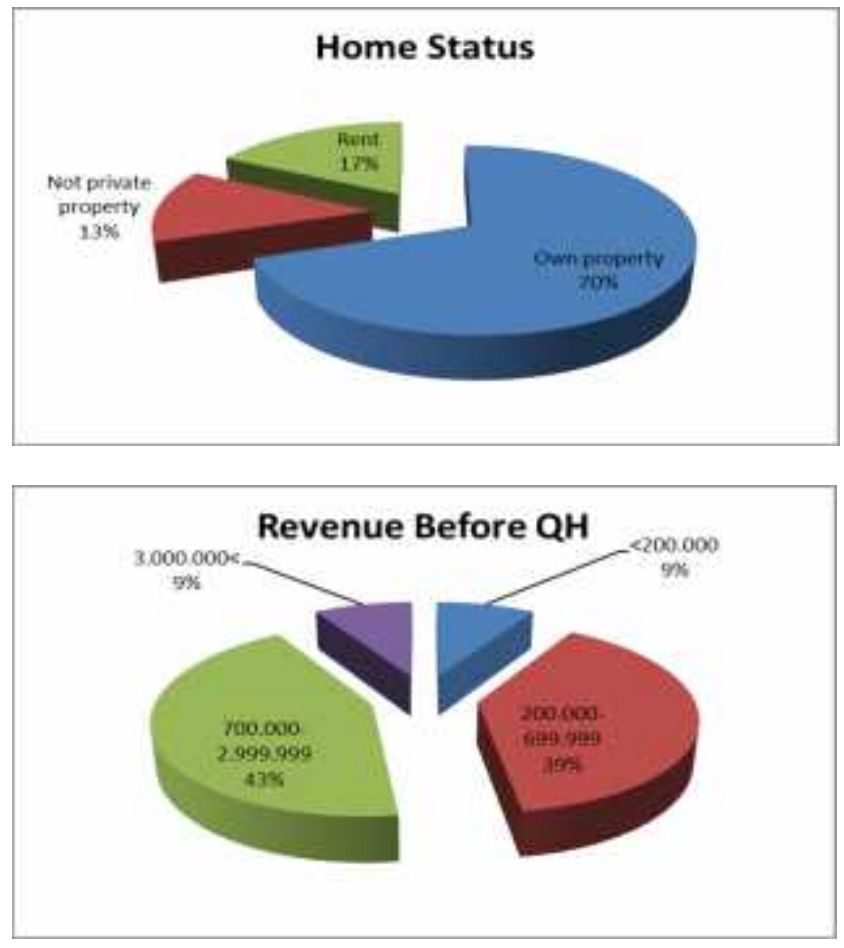

Fig. 2. Overview receiver Qardhul Hasan Islamic Bank in Bandung. Source: Result of data processing

Based on Picture 4.1, it is also evident that the receiver qardhu hasan Islamic bank in Bandung either distributed directly by the bank or through LAZ majority (73\%) of those who have had business activities but still does not meet the requirements for submission to the bank, while the remaining $27 \%$ is poor. The average income of the recipient qardhu hasan time of filing largely is between Rp. 700000-2900000, -. If it is associated with PBI No.

\subsection{Optimization of Qardhul Hasan Sharia Bank to Poverty Reduction in Bandung}

As mentioned before to see the effectiveness and efficiency of the distribution qardhu hasan Islamic banks there are indicators of success include the increase in revenue that can improve the status of poor people (recipients $=$ mustahik) become tax payers (muzzaki). It is necessary to describe the condition before and after receiving qardhu hasan.

The research showed a picture as shown in the following table:

TABLE III. OVERVIEW RECEIVER QARDHU HASAN BEFORE AND AFTER RECEIVING QARDHU HASAN IN B ANDUNG

\begin{tabular}{|l|l|l|}
\hline \multicolumn{1}{|c|}{ Variable-Indicator } & \multicolumn{1}{c|}{ Before } & \multicolumn{1}{c|}{ After } \\
\hline Income average & 1.297 .614 & 1.505 .795 \\
\hline Saving & 21,7 persen & 100 persen \\
\hline Mindset & 42,51 persen & 90,01 persen \\
\hline \multicolumn{2}{|c}{${ }^{c}$. Source: Result of data processing } \\
\hline \multicolumn{2}{|l}{}
\end{tabular}

Based on Table 4.3 above, it appears that qardhu hasan Islamic banks are channelled in Bandung has been able to bring changes to the household income, saving awareness and change the paradigm of mind-set community, especially with regard to discipline in paying the instalments as well as awareness of saving. Thinking paradigm change can't be separated from the facilitation do. They are given the motivation that the work is not merely to make a living but to worship so that they become more vigorous and upright. They are encouraged to share and help the poor or those who have not been empowered to become donors. Once they are sufficient and not to become greedy, are encouraged to practice social form of alms or a special donation for empowerment.

Linkage to change the status of Mustahiq be muzzaki, apparently no one has categorized muzzaki because it has not yet reached nishab zakat. However, if studied further, with their pay installments of principal only in their current state, actually they has helped in the revolving fund, so that the funds can be rolled out to other communities. Instead, they are required to carry out the payment process smoothly with the right intention, through a process consistent with the goals and the teachings of religion, in order to help create fairness, equality, and prosperity for mankind. The installment payments are invested on the basis of faith, as one dimension of monotheism professed Moslem.

Under these conditions, it is qualitatively qardhu hasan can be said that Islamic banks have a positive impact on the lives of recipients. In other words that qardhu hasan qualitatively Islamic banks able to decreasing poverty in Bandung. This conclusion is reinforced interviews with managers LAZ, one of which management of DPU DT. "Thank God had a lot of dhuafa and poor people, especially mothers who become members Misykat. I see there are some works of their hand made creation such as flower ornaments, cap and glove knitting cell phone, snacks, salted egg, chicken claw and other chips, which are sold in the Pesantren Daarut Tauhid. From the reports, it appears that they have increased the economy and begin to engage in religious activities in the neighborhood. I think this is clear evidence that the funds Muslims, be it zakat or alms could be a solution to empower people".

Based on statistical test with different test an average result of 0.87 is smaller than $t$ table 1.658 this gives an indication that there is a difference between the condition before and after receiving qardhu hasan so it can be said not effective. This conclusion is consistent with the test results Stats Spearman rank correlation of 0.35 . This identifies that the poverty rate in the city of Bandung with qardhu hasan Islamic banks there was a significant relationship. This is expected of the existence of other factors that affect poverty through structural and cultural dimensions. This implies that social relationships and social interactions that are typical in the community resulted in the course of a habit that can restrict the initiative and the spirit of community residents to develop. Ongoing submissive attitudes, lack of creativity, initiative and daring in the community or indirectly can 
perpetuate forms and distinctive features in the communities included in a family.

\section{CONCLUSION}

Based on the results and the preceding discussion, then as the cover of this study can be concluded as follows:

1) The effectiveness of management qardhu hasan managed by LAZ with by Sharia banks in the city are more effective than managed directly by the Sharia Bank.

2) Qardhu hasan Sharia banks have been able to bring changes to the household income, saving awareness and change the paradigm of thinking, especially with regard to discipline in paying the installments as well as awareness of saving.

3) Qualitatively qardhu hasan Sharia banks have been able to reduce poverty in the city but in statistics not show a significant effect.

Based on these conclusions, the suggestions can be given is as follows:

1) Qardhu hasan owned Sharia bank in the distribution preferably through the Amil Zakat

2) It needs regulations requiring that products qardhul has become a mandatory program in Sharia banks as a differentiated between Sharia banks with conventional banks.

3) In the distribution, must be clear definition of poverty so that in distribution is not misdirecte

4) It should to conduct socialization on qardhul hasan in which the activities necessary involvement of the academic elements, actors, and government.

\section{REFERENCES}

[1] Abdul Aziz Rifa'i (2011) "Optimalisasi Pengelolaan ZIS di Indonesia". http://beritanda.com/ nasional/berita-nasional/sosial-budaya/3037optimalisasi-pengelolaan-zis-di-indonesia.html

[2] Adiwarman Karim ( 2003) "Bank Islam (Analisis Fiqih dan Keuangan)". Penerbit PT.Raja Grafindo Persada, Jakarta

[3] Akhyar Adnan dan Firdaus Furywardhana (2006). Evaluasi Non Performing Loan (Npl) Pinjaman Qardhul Hasan (Studi Kasus di BNI Syariah Cabang Yogyakarta). JAAI VOLUME 10 NO. 2, DESEMBER 2006: 155 - 171

[4] Amir Machmud (2007) Analisis Faktor-faktor Penyebab NonPerforming Financing . Jurnal Indonesia Membangun Vol 6 No.1 Maret-Juni 2007, ISSN 1412-6907
[5] ----------------- (2008) Bank Syariah Sebagai Alternatif Pembiayaan Usaha Kecil dan Menengah di Indonesia. Jurnal Indonesia Membangun Vol 7 No.1 Maret-Juni 2008, ISSN 1412-6907.

[6] ------------------(2008) Analisis Efisiensi BPD Unit Usaha Syariah di Indonesia. Jurnal Indonesia Membangun Vol 7 No.1 Nopember 2008 - Februari 2009, ISSN 1412-6907

[7] ----one-(2009) Model Kemitraan Pelaku Usaha Mikro Kecil Menengah Kota Bandug. Buletin Ekuitas Vol II No 2 Desember 2008, ISSN 1778-1466

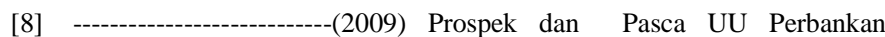
Syariah. Koran Pikiran Rakyat Tanggal 2 Maret 2009

[9] ---------------- (2009) Perbandingan Sistem Moneter Syariah dengan Konvensional . Buletin Ekuitas Vol II No 1 Juni 2009 , ISSN 1778-1466.

[10] -----oro Bank Syariah: Teori, Kebijakan dan Studi Empirik di Indonesia. Penerbit Erlangga, Jakarta

[11] ----ol---(2011). Peluang dan Tantangan Ekonomi Islam di Indonesia. Makalah disampaikan dalam Konvensi Keuangan dan Perbankan. STIE Ekuitas, Mei 2011.

[12] ------------(2012) Efiensi BUS di Indonesia. Artikel pada Info Bank Syariah Media Informasi Ekonomi dan Perbankan Syariah. Edisi Januari 2012

[13] -----o----o13) Problemaika SDI Bank Syariah. Artikel pada harian umum Pikiran Rakyat, Senin 11 Februari 2012.

[14] Antonio, Syafi'i (2001) Bank Syari'ah dari Teori ke Praktek. Jakarta: Gema Insani Press

[15] Ascarya (2007) Akad dan Produk Bank Syariah. Jakarta : PT. Raja Grafindo persada.

[16] Bappenas (2010). "Perkembangan Keuangan Mikro Untuk Kemiskinan". http:// ditpk.bappenas.go.id/ ?nav $=4 \& m=$ content $\& s=$ artikel $\& a=v i e w \& i d=309$

[17] Bank indonesia (2005). Peraturan Bank Indonesia No 7/46/PBI/2005.

[18] Edi Siswadi (2011) "Strategi Kemiskinan di Kota Bandung". http://basis13.com/index.php? option=com_ content \&view $=$ article \&id $=353$

[19] Evi Damayanti, (2012) Angka Kemiskinan di kota Bandung Menurun. http://.inilah. com/read/ detail/1859075/

[20] Muhammad Maslehuddin. (1994). Sistem Perbankan Dalam Islam. Jakarta: Rineka Cipta

[21] Perwataatmadja dan M. Syafi'i Antonio. (1999). Apa dan Bagaimana Bank Islam. Penerbit Dana Bhakti Prima Yasa, Yogyakarta.

[22] Rifki Ismail (2012) Blue Print Pengembangan Perbankan Syariah yang Ke-Indonesiaan Makalah disampaikan pada Seminar dan Musyawarah Nasional ASBISINDO, Jakarta, 21 Maret 2012.

[23] Smeru (2002) Kemiskinan di Indonesia. http://ismailrasulong.files.wordpress.com / 2011/ 04/kondisikemiskinan-di-indonesia.pdf

[24] Smeru (2008). Peta Kemiskinan Indonesia: Asal Mula dan Signifikansinya. http:// www.smeru.or.id/ newslet/2008/news26.pdf

[25] Yusuf Qardhawi (1997) Norma dan Etika Ekonomi Islam. Penerbit Gema Insani Press, Jakarta . 